\title{
Kultur Asrama Berbasis Sekolah Sebagai Pusat Pembinaan Karakter di SMPIT Al-Furqon Palembang
}

\section{Munir}

Fakultas Ilmu Tarbiyah dan Keguruan

Universitas Islam Negeri Raden Fatah Palembang, Indonesia

Email: munir_uin@radenfatah.ac.id

\begin{abstract}
Abstrak
Artikel ini merupakan hasil penelitian yang mendeskripsikan tentang kultur asrama di SMPIT Al-Furqan Palembang, memahami makna filosofis asrama bagi masyarakat belajar SMPIT Al-Furqan Palembang, serta memahami sistem nilai dalam kultur tersebut pada konteks pendidikan Islam kontemporer. Penelitian ini merupakan penelitian lapangan, yakni dengan menjadikan SMPIT Al-Furqan Palembang sebagai objek penelitian. Sedangkan sumber primer dalam penelitian ini, yakni berasal dari hasil observasi dan didukung juga dengan hasil wawancara. Sedangkan yang menjadi informan dalam kajian ini adalah para siswa dan para tenaga pendidik, pembina dan kepala asrama, kepala sekolah, pengurus dapur, petugas keamanan dan ketertiban asrama, kantin dan toko di sekitar asrama, serta beberapa orang wali siswa. Artikel ini menyimpulkan bahwa karakter yang ingin ditanamkan kepada setiap siswa/ peserta didik di SMPIT AlFurqan Palembang, yakni: religious, jujur, toleransi, disiplin, kerja keras, kreatif, mandiri, demokratis, peduli lingkungan, peduli sosial, dll. Karakter ini akan dicapai dengan membuat tata tertib peraturan, panduan dan sangsi atas setiap pelanggaran.
\end{abstract}

\begin{abstract}
This article is the result of research that describes about the dormitory culture at Al-Furqan SMP IT Palembang, understanding the philosophical meaning of hostels for people to learn SMPIT Al-Furqan Palembang, as well as understanding the value system of the culture in the context of contemporary Islamic education. This research is a field study, by making SMP IT Al-Furqan Palembang as research objects. While the primary source in this study is derived from the observation and supported also by the results of the interview. While the
\end{abstract}

Intizar, Vol. 22, No. 2, 2016 
informants in this study are students and educators, teachers and matron, principals, kitchen staffs, security guards and order cafeterias and shops around the dormitory, as well as several students' parents. The article concludes that the character who wants to be imparted to each student / learner in SMP IT AlFurqan Palembang, namely: religious, honest, tolerant, disciplined, hard work, creative, independent, democratic, environmental care, social care, and so on. These characters will be achieved by making the disciplinary regulations, guidelines and sanctions for any violations.

\section{Keywords: Education in Dormitory, Character Development}

Bila kita perhatikan secara cermat, dewasa ini ada fenomena pendidikan yang sangat menarik untuk diteliti secara ilmiah, yaitu munculnya sekolah dan madrasah berasrama (boarding school). Fenomena ini tergolong baru, sebab sebelumnya lembaga pendidikan yang berasrama pada umumnya terjadi pada pondok pesantren, atau setidaknya lembaga pendidikan khusus yang dipersiapkan untuk mencapai standar keterampilan tertentu yang memang sangat membutuhkan lingkungan yang terpadu. Sementara itu, untuk sekolah atau madrasah umum, lazimnya tidak berasrama.

Perkembangan pendidikan di Indonesia pada umumnya dan bahkan telah pada tingkat daerah, kini telah mengalami perubahan dan pergeseran yang cukup signifikan. Perubahan itu diantaranya adalah munculnya sekolah dan madrasah dengan mencantumkan karakteristiknya masing-masing, misalnya madrasah model, sekolah unggulan, sekolah bertaraf nasional, sekolah Islam terpadu dan lain-lain. Pencantuman label pada nama sekolah tersebut, ternyata berimplikasi pada sistem manajemen, sistem pembelajaran dan kultur pendidikan yang khas.

Fenomena munculnya karakteristik madrasah dan sekolah tersebut di atas, juga terjadi di Kota Palembang. Salah satunya yaitu Sekolah Menengah Pertama Islam Terpadu (SMPIT) Al-Furqon Palembang, menggunakan istilah SMPIT bertaraf internasional. Di antara karakteristik yang menonjol dari madrasah tersebut adalah memiliki asrama sebagai sarana dan lingkungan pendidikan yang mereka kondisikan. Sekolah Menengah Pertama Islam Terpadu SMPIT Al-Furqon Palembang mewajibkan seluruh peserta didik kelas IX untuk menginap di asrama. Bagi siswa kelas VII dan VIII yang ingin tinggal di asrama, maka diperbolehkan.

Secara sosiologis, lembaga pendidikan pada dasarnya merupakan sebuah komunitas atau masyarakat. Sebagai sebuah komunitas, lembaga pendidikan 
memiliki budaya dan kultur tersendiri yang berlaku bagi seluruh anggota komunitas yang bersangkutan. Kultur sebuah masyarakat dibentuk berdasarkan konsensus antar anggota dalam upaya mencapai tujuan komunitas itu sendiri. Oleh karena itu, setiap kultur memiliki struktur yang berfungsi untuk menjalankan misi besar masyarakat dan sebagai faktor penentu pencapaian cita-cita luhur sebuah komunitas.

Ketika SMPIT Al-Furqon Palembang membangun asrama sebagai salah satu strukturnya, maka ada misi tertentu yang ingin dicapainya dan ada fungsi tertentu yang diharapkan dapat diperankan oleh asrama tersebut dalam konteks pencapaian misi dan tujuan SMPIT AL-FURQON Palembang secara keseluruhan. Ada harapan besar yang ingin diraih dengan pendirian dan pemanfaatan asrama tersebut dalam konteks pencapaian tujuan lembaga secara keseluruhan.

\section{Asrama Sekolah dan Urgensinya dalam Pembinaan Karakter Siswa}

Kajian tentang kultur madrasah dan sekolah yang berasrama, tampaknya belum banyak dilakukan oleh para ahli. Kalau tradisi belajar di asrama dalam konteks pesantren, memang telah banyak dilakukan para ahli ${ }^{1}$ namun kajian tentang Kultur Madrasah dan sekolah berasrama, tampaknya masih sangat langka, apalagi dalam konteks Kota Palembang. Dengan demikian tampak bahwa penelitian tentang Kultur Madrasah dan sekolah berasrama di Kota Palembang adalah merupakan kajian baru. Kajian ini menjadi penting karena fenomena tentang Madrasah dan sekolah berasrama di Kota Palembang mulai menggejala dan terlihat menjadi sebuah trend baru bentuk lembaga pendidikan dengan berciri khas. Oleh karena itu kajian ini tentu menjadi sebuah kajian yang cukup menarik dan aktual.

Dalam kehidupan manusia tidak akan terlepas dari hubungan dengan individu lain yang ada di sekitarnya karena manusia adalah makluk sosial. Usaha manusia untuk berhubungan dengan manusia lainnya ini diatur oleh norma atau aturan yang dibuat dan disepakati bersama untuk melindungi kepentingan masingmasing. ${ }^{2}$ Norma ini bersifat mengikat masing-masing individu yang menjadi bagian dari hubungan tersebut. Norma yang terbentuk dan berkembang di suatu masyarakat memunculkan sanksi-sanksi yang memaksa masing-masing individu untuk menaatinya. Norma yang mengatur cara individu bersikap dan bertingkah laku ini disebut dengan tradisi, sehingga tradisi merupakan cara individu bersikap sesuai dengan norma yang dianut oleh masyarakatnya, cara bertindak ini didasarkan atas pengalaman yang dimiliki oleh masyarakat tersebut.

Intizar, Vol. 22, No. 2, 2016 
Setiap kelompok sosial atau komunitas mempunyai sistem tersendiri untuk mempertahankan eksistensinya. Dalam mempertahankan eksistensinya, setiap kelompok atau komunitas sosial akan selalu berusaha untuk menanamkan dogtrin ajarannya yang dianggap sebagai sesuatu yang subtansial atau mendasar. Dogtrin itu sendiri pada umumnya diterjemahkan ke dalam nilai-nilai tradisi atau budaya yang terus diwariskan dari generasi ke generasi berikutnya. ${ }^{3}$ Salah satu strategi untuk menjamin berlangsungnya penanaman dan pewarisan tradisi tersebut adalah dengan dibentuknya tata aturan yang berupa hukum, undang-undang, peraturan atau tata tertib. Tata tertib atau tata hukum tersebut berisi tentang kewajibankewajiban yang harus dipatuhi oleh komunitas tersebut. ${ }^{4}$ Demikian juga dengan yang terjadi pada Madrasah/sekolah berasrama di Kota Palembang.

Penelitian ini berusaha mengkaji ragam kultur madrasah/ sekolah berasrama di Kota Palembang. Penelitian diharapkan dapat mendiskripsikan kultur madrasah/sekolah berasrama di Kota Palembang apa adanya, tanpa adanya praduga atau hipotesa yang akan diuji, tetapi penelitian ini justru lebih menekankan pada upaya mengungkap, mendiskripsikan dan memahami proses pembentukan kultur madrasah/sekolah berasrama serta menangkap makna-makna yang terkandung di dalam kultur sendiri.

Oleh karena itu penelitian menggunakan pendekatan etnografis fenomenologis. Pendekatan ini lazim digunakan dalam penelitian sosiologi dengan maksud memahami gejala-gejala sosial yang terjadi di kalangan madrasah/sekolah berasrama. Mengapa etnografis digunakan?. Etnografis digunakan, karena penelitian tentang kultur madrasah/sekolah berasrama termasuk kajian bidang penelitian yang masih relatif langka dan belum banyak literatur maupun penelitian dalam bidang ini, sehingga belum banyak analisis tentang aspek ini. Untuk kajian yang bersifat mendiskripsikan seperti ini diperlukan agar tidak terjebak dalam reduksi dan justifikasi atas kategori tertentu yang dapat memalingkan fenomena yang sebenarnya, tetapi justru berusaha mengungkapkan fenomena yang senyatanya tanpa adanya penafsiran-penafsiran tertentu dari peneliti.

Sedangkan fenomenologis digunakan, agar peneliti dapat mengungkap makna atau nilai-nilai laten yang ada di balik realitas atau fenomena kultur itu menurut persepsi masyarakat madrasah/sekolah berasrama sendiri. ${ }^{5}$ Mengapa demikian?. Peneliti meyakini bahwa dalam setiap fenomena sosial termasuk kultur madrasah/sekolah berasrama tidak akan terjadi begitu saja, tetapi merupakan sebuah upaya yang disengaja dengan dasar filosofis dan pandangan hidup tetentu, yang didasari oleh nilai-nilai yang hakekat kebenarannya ada pada masyarakt yang 
bersangkutan, baik yang bersumber dari keyakinan terhadap ajaran agama maupun yang bersumber dari hasil interaksi dengan lingkungan sosial.

Dilihat dari perspektif sosiologis dan antropologis, asrama sebagai tempat tinggal peserta didik merupakan fakta sosial yang sangat menarik untuk diamati. Hal ini disebabkan karena keberadaan asrama itu sebagai kelompok, komunitas atau masyarakat baru yang terbentuk atas konsensus dan prosesnya sangat cepat, berbeda dengan masyarakat pada bangsa atau etnis tertentu yang pada umumnya memerlukan jangka waktu yang sangat lama. Selaian itu, bahwa anggota masyarakat yang baru terbentuk ini pada umumnya memiliki latarn budaya dan struktur mayarakat yang berbeda serta memiliki karakter yang beragam. Oleh karena, tentu saja akan terjadi proses sosialisasi.

Pada dasarnya sosialisasi adalah soal belajar. Dalam proses sosialisasi, individu akan belajar bertingkah laku, kebiasaan dan pola-pola kebudayaan lainnya, juga keterampilan-keterampilan sosial seperti berbahasa, bergaul, berpakaian, cara makan dan sebagainya. ${ }^{6}$ Segala sesuatu yang dipelajari individu harus dipelajari dari anggota masyarakat lainnya secara sadar, seperti apa yang dipelajari dari orang tua, guru, senior, pengasuh, pendamping, pembimbing dan seterusnya.

Sosialisasi terjadi melalui "conditioning" oleh lingkungan yang menyebabkan individu mempelajari pola kebudayaan yang fundamental, subtansial dan sangat mungkin bersifat formal dan berlaku secara komulatif. Bahkan bila dicermati lebih jauh dapat ditemukan adanya proses sosial yang berlangsung secara privat, tidak formal namun memiliki pengaruh yang sangat kuat terhadap terbentuknya karakter budaya tertentu. Interaksi "peer teaching, peer learning, dan hiden curriculum" lainnya dalam sebuah lingkungan tertentu pada sesama anggota komunitas akan terjadi lebih intens, fleksibel dan fungsional. Kondisi ini akan sangat menguntungkan, prosesnya tidak membutuhkan dana yang terlalu besar dan juga tidak membutuhkan birokrasi yang panjang dan rumit. Fenomena ini merupakan fakta sosial yang seharusnya dapat dimanfaatkan secara optimal dan fungsional. Kecerdasan dalam memanfaatkan potensi sosial yang ada akan melahirkan modal sosial yang besar, yang pada giliramnnya menjadi daya dukung. ${ }^{7}$

Dalam konteks pendidikan Islam tradisional, asrama seringkali disebut dengan istilah pondok. Pondok pada umumnya dipahami sebagai pemukiman para santri, merupakan ciri khas tradisi pesantren, yang membedakannya dengan sistem pendidikan tradisional di masjid-masjid yang berkembang di kebanyakan wilayah 
Islam di negara-negara lain. ${ }^{8}$ Bahkan, sistem asrama ini pula yang membedakan pesantren dengan sistem pendidikan surau di daerah Minangkabau.

Di Afghanistan misalnya, para murid dan guru-gurunya yang belum menikah tinggal di masjid. Jika masjid tersebut cukup luas, satu atau dua kamar yang disebut hujrah dibangun di samping masjid untuk tempat tidur para murid dan guru-guru. Kebanyakan murid tinggal menyebar di langgar-langgar yang berdekatan dengan masjid yang besar tersebut. Para murid di langgar-langgar ini biasanya memimpin shalat lima waktu bagi jamaah (masyarakat) setempat; dan atas kedudukannya ini masyarakat menanggung kebutuhan makan para $t\} u l l a>b$ (murid). Pada musim panen, sebagian hasil panen disedekahkan kepada $t\} u l l a>b$ sebagai hak Allah. Sedekah ini biasanya dibelanjakan oleh t\}ulla $>b$ untuk kebutuhan pakaian dan uang saku mereka.

Di Jawa, besarnya pondok tergantung dari jumlah santri. ${ }^{9}$ Pesantren besar yang memiliki santri lebih dan 3.000 orang, ada yang telah memiliki gedung bertingkat tiga yang dibuat dari tembok; semua ini biasanya dibiayai dari para santri dan sumbangan masyarakat. Tanggung jawab santri dalam pendirian dan pemeliharaan pondok diselenggarakan dengan cara yang berbeda-beda.

Ada tiga alasan utama kenapa pesantren harus menyediakan asrama bagi para santri. Pertama, kemasyhuran seorang kyai dan kedalaman pengetahuannya tentang Islam menarik santri-santri dari jauh. Untuk dapat menggali ilmu dari kyai tersebut secara teratur dan dalam waktu yang lama, para santri tersebut harus meninggalkan kampung halamannya dan menetap di dekat kediaman kyai. Kedua, hampir semua pesantren berada di desa-desa di mana tidak tersedia perumahan (akomodasi) yang cukup untuk dapat menampung santri santri; dengan demikiàn, perlulah adanya suatu asrama khusus bagi para santri.

Ketiga, ada sikap timbal balik antara kyai dan santri, di mana para santri menganggap kyainya seolah-olah sebagai bapaknya sendiri, sedangkan kyai menganggap para santri sebagai titipan Tuhan yang harus senantiasa dilindungi. Sikap timbal balik ini menimbulkan keakraban dan kebutuhan untuk saling berdekatan terus-menerus. Sikap ini juga menimbulkan perasaan tanggung jawab di pihak kyai untuk dapat menyediakan tempat tinggal bagi para santri. Di samping itu, dari pihak para santri tumbuh perasaan pengabdian kepada kyainya, sehingga para kyai memperoleh imbalan dari para santri sebagai sumber tenaga bagi kepentingan pesantren dan keluarga kyai.

Di negara-negara Islam yang lain, para ulama kebanyakan merupakan penduduk kota. Dengan demikian, para murid dari jauh yang belajar di bawah 
bimbingan ulama tersebut dapat menyewa tempat tinggal di sekitar rumah gurunya, yang biasanya tersedia cukup banyak. Di Mekah dan Madinah misalnya, yang merupakan dua pusat utama bagi studi Islam tradisional, para ulama mengajar murid-muridnya di Masjidil Haram dan Masjid Nabawi. ${ }^{10}$ Para murid yang kebanyakan datang dari luar negeri, tinggal dalam koloni-koloni. Universitas Al-Azhar di Kairo Mesir menyediakan akomodasi dalam komplek universitas, tetapi tidak seperti pesantren. Al-Azhar berkembang dari sistem pendidikan masjid tradisional di mana pemerintah memegang inisiatif penting dan yang akhirnya menjadi instansi milik masyarakat sepenuhnya.

Pentingnya pondok sebagai asrama para santri tergantung kepada jumlah santri yang datang dari daerah-daerah yang jauh. Untuk pesantren kecil misalnya, para santri banyak pula yang tinggal di rumah-rumah penduduk di sekitar pesantren; mereka menggunakan pondok hanya untuk keperluan-keperluan tertentu saja. Untuk pesantren besar seperti Tebuireng, para santri harus puas tinggal bersama-sama dengan sepuluh sampai dengan lima belas santri dalam satu kamar sempit (kira-kira 8 meter persegi). Tidak semua santri dapat tidur dalam kamar tersebut di waktu malam; beberapa di antaranya tidur di serambi masjid. Ada sekitar 200 santri tidur di serambi masjid Tebuireng setiap malam. Para santri ini sebenarnya terdaftar di kamar-kamar tertentu di mana mereka menyimpan pakaian dan barang-barang milik yang lain.

Fenomena asrama di lembaga pendidikan Islam modern, khususnya untuk kategori lembaga pendidikan umum tampaknya merupakan fenomena yang relatif baru. Fenomena munculnya asrama pada sekolah-sekolah Islam dan madrasah tampaknya seiring dengan munculnya Kurikulum Tingkat Satuan Pendidikan (KTSP) tahun 2006, yang menekankan pentingnya pendidikan karakter dalam pendidikan.

Sejak munculnya Kurikulum Tingkat Satuan Pendidikan (KTSP) tahun 2006, beberapa jenis lembaga pendidikan mendirikan asrama sebagai tempat tinggal para siswa, terutama sekolah-sekolah atau madrasah yang mencantumkan istilah unggulan, terpadu atau model pada visi misi lembaga pendidikannya. Hampir semua pemerintah provinsi, kabupaten atau kota memiliki sekolah unggulan, dan pada umumnya menyertakan asrama dalam lingkungan sekolah. Jaringan Sekolah Islam Terpadu Indonesia (JSIT), juga membangun asrama untuk para siswa-siswi mereka. Marasah-madrasah model yang berada di bawah naungan Kementerian Agama, juga membangun asrama untuk para siswa mereka.

Intizar, Vol. 22, No. 2, 2016 
Pembangunan asrama sebagai salah satu fasilitas pendidikan di sekolah atau madrasah, tampaknya memiliki dampak positif terhadap animo masyarakat untuk memilih lembaga pendidikan yang bersangkutan. Memang belum ada penelitian secara khusus tentang alasan mendasar yang melatarbelakangi para orang tua memilih sekolah atau madarasah yang berasrama sebagai tempat pendidikan anak-anak mereka. Namun sudah menjadi gejala umum bahwa setiap sekolah atau madrasah yang berasrama pada umumnya memiliki peminat yang tinggi, sungguhpun biaya pendidikan yang dibebankan kepada para orangtua relatif cukup tinggi.

Secara sosiologis, asrama pendidikan pada dasarnya merupakan sebuah sistem sosial. Sebagai sistem sosial, asrama pendidikan memiliki elemen-elemen penting untuk mencapai tujuan bersama warga asrama dan tujuan masyarakat yang lebih besar dan lebih luas. Elemen-elemen tersebut biasanya saling terkait dan saling mempengaruhi. Setiap elemen pada umumnya menunjukkan strukturnya masing-masing dengan karakteristik kultur tertentu. Setiap struktur memiliki fungsi tertentu untuk mencapai tujuan tertentu dan memiliki cara tertentu yang diyakini sebagai strataegi yang jitu untuk menanamkan sebuah kultur yang dikehendaki.

Secara managerial, asrama pendidikan dipandang sebagai sebuah sistem yang terdiri atas beberapa elemen penting, yaitu perencanaan, pengorganisasian, pelaksanaan, pengawasan dan pembiayaan. Asrama pendidikan akan dapat mendukung pencapaian tujuan lemabaga secara keseluruhan, jika dikelola secara baik, efektif dan efisien. Efektifitas dan efisiensi pengelolaan asrama pendidikan, pada umumnya dipengaruhi oleh faktor internal dan eksternal. Kedua faktor ini harus ada, saling mendukung dan melengkapi dalam pengelolaan asrama.

Ketika berbicara mengenai urgensi asrama dalam konteks pesantren, orang tidak lagi ragu tentang fungsi dan perannya dalam membentuk karakter santri. Hal ini disebabkan keberadaan asrama memang bagian yang tak terpisahkan dan sistem pendidikan pesantren. Memang sejak awal pesantren didirikan untuk menyelenggarakan pendidikan yang lebih menekankan pada aspek relegiusitas dan moralitas santri. Sehingga mutlak diperlukan asrama atau pemondokan sebagai lingkungan kehidupan sehari-hari. Dengan demikian sangat jelas bahwa asrama atau lingkungan tempat tinggal para santri dan kyai serta para dewan pendidik mempunyai fungsi ganda, yakni sebagai tempat tinggal dan menjadi laboratorium agama sekaligus.

Intizar, Vol. 22, No. 2, 2016 
Menjadi hal yang sangat menarik, bila kita berbicara mengenai asrama siswa sebagai pusat pembentukan karakter peserta didik, mengapa demikian?. Sebab jika dalam konteks pesantren sangat jelas bahwa kyai sebagai pendiri atau pemimpin pesantren, ia menjadi pusat figur dan pemilik visi tunggal pesantrennya. Bahkan pesantren itu sendiri merupakan cermin kepribadian kyai itu sendiri, baik dari keyakinan yang dimiliki, mazhab fiqih dan pemikiran yang dianut, maupun konsep kebenaran yang ingin ia kembangkan. Sedangkan sekolah, siapa yang menjadi pusat figur, dan siapa yang akan menjadi dasar sumber nilai utama?.

Namun demikian, sudah menjadi kenyataan bahwa telah banyak dan cenderung terus bertambah sekolah-sekolah atau madrasah yang membangun asrama sebagai tempat tinggal siswa atau peserta didik. Menurut beberapa ahli sosiologi dan pendidikan bahwa asrama justru sangat efektif sebagai pusat pendidikan dan pengembangan sistem nilai dan karakter peserta didik. Mereka mengatakan bahwa, sistem interaksi di lingkungan sekolah formal yang hanya mengandalkan proses pencapaian kurikulum faktual tidak cukup untuk membentuk karakter dan sistem nilai di kalangan peserta didik.

Keterbatasan waktu, target capaian kurikulum yang tinggi, serta banyaknya agenda pembelajaran tidak memungkinkan para guru menanamkan sistm nilai dan pembentukan karakter secara lebih serius. Hal ini disebabkan oleh kenyataan bahwa setiap guru lebih konsentrasi pada tugas kulikuler yang dibebankan kepadanya, yakni jumlah jam tatap muka sebanyak 24 kali disertai dengan tugas-tugas pra dan pasca pembelajaran. Selain itu, tugas dalam penanaman sistem nilai dan karakter cenderung luput dari penghargaan atau tidak termasuk tugas yang bisa mengurangi beben mengajarnya.

Sungguhpun demikian, namun keberadaan asrama sebagai tempat tinggal peserta didik sudah barang tentu memiliki fungsi sosial tertentu yang berhubungan dengan proses pendidikan dan pembelajaran secara lebih luas. Jika dimanfaatkan dikelola secara baik dan tepat, asrama siswa justru menjadi sarana efektif untuk pembentukan sebuah budaya sekolah yang diinginkan. Asrama siswa bisa dimanfaatkan untuk menyemai nilai-nilai budaya luhur bangsa dan agama, dan menjadi laboratorium agama dan sosial yang efektif.

Hal inilah yang sebenarnya menjadikan sekolah berasrama kini menjadi incaran banyak orang tua. Para orang tua berharap dengan asrama siswa yang dikelola oleh pihak sekolah dan banyak guru yang terlibat didalamnya, akan menjalin keamanan para peserta didik dari ancaman bahaya narkoba, penyalahgunaan alat ICT dan sejenisnya.

Intizar, Vol. 22, No. 2, 2016 
Teori belajar sosiokultur menyatakan bahwa pentingnya sebuah pendidikan melihat harus memperhatikan proses kebudayaan dan pendidikan yang tidak bisa dipisahkan. Pendidikan dan kebudayaan memiliki keterkaitan yang sangat erat, di mana pendidikan dan kebudayaan berbicara pada tataran yang sama, yaitu nilai-nilai. Tylor dalam H.A.R Tilaar telah menjalin tiga pengertian manusia, masyarakat dan budaya sebagai tiga dimensi dari hal yang bersamaan. Oleh sebab itu pendidikan tidak dapat dilepaskan dari kebudayaan dan hanya dapat terlaksana dalam suatu komunitas masyarakat.

Budaya adalah sesuatu yang general dan spesifik sekaligus. ${ }^{11}$ General dalam hal ini berarti setiap manusia di dunia ini mempunyai budaya, sedangkan spesifik berarti setiap budaya pada kelompok masyarakat adalah bervariasi antara satu dan lainnya. Budaya atau peradaban adalah suatu keseluruhan yang kompleks dari pengetahuan, kepercayaan, seni, moral, hukum, adat istiadat, serta kemampuaan kemampuan dan kebiasaan lainnya yang diperoleh manusia sebagai anggota masyarakat".

Kebudayaan merupakan suatu proses pemanusiaan yang artinya di dalam kehidupan berbudaya terjadi perubahan, perkembangan dan motivasi. ${ }^{12}$ Pentingnya kebudayaan dalam kehidupan manusia inilah yang kemudian mendasari bahwa kebudayaan tidak bisa dilepaskan dari pendidikan. Melihat kondisi bangsa Indonesia yang terdiri dari berbagai budaya. Masyarakat yang harus mengekspresikan pendidikan kebudayaan adalah masyarakat yang secara obyektif memiliki anggota yang heterogenitas dan pluralitas.

Pentingnya menghargai budaya dalam pendidikan ini karena dorongan yang timbul dalam diri manusia sadar ataupun tidak sadar adalah hasil kebudayaan di mana pribadi itu hidup. Perkembangan kepribadian manusia dalam kebudayaan dilihat dari pandangan behaviorisme dan psikoanalitis, yakni: 1). Kebudayaan memberikan kondisi yang disadari dan yang tidak disadari untuk belajar; 2). Kebudayaan mendorong secara sadar ataupun tidak sadar akan reaksi-reaksi kelakuan tertentu; 3). Kebudayaan mempunyai sistem "reward and punishment", terhadap kelakuan-kelakuan tertentu. Setiap kebudayaan akan mendorong setiap kelakuan yang sesuai dengan sistem nilai dalam kebudayaan tersebut dan sebaliknya memberikan hukuman terhadap kelakuan-kelakuan yang bertentangan atau mengusik ketenteraman hidup suatu masyarakat budaya tertentu. 4). Kebudayaan cenderung mengulang bentuk-bentuk kelakuan tertentu melalui proses belajar.

Intizar, Vol. 22, No. 2, 2016 


\section{Asrama dan Pewarisan Budaya}

Kesadaran pemerintah dan beberapa sekolah ini kelihatannya mulai terlambat dilaksanakan mengingat bahwa seharusnya pelaksanaan sistem asrama bukan hanya dilakukan bila keadaan dan situasi menuntut untuk dilakukan sistem asrama pada waktu-waktu tertentu saja. Namun seharusnya jauh-jauh hari sebelumnya, yakni sejak menginjak bangku kelas 1 SMP atau SMA, para siswa/siswi itu semestinya sudah harus diasramakan demi perhatian yang lebih serius terhadap proses pendidikan pendidikan intelektual, emosi dan spiritual.

Berbicara tentang pendidikan dengan sistem asrama sejauh ini, hanya dua lembaga yang boleh dikatakan memperlakukan secara ketat pendidikan berasrama, yakni pendidikan seminari dan pendidikan pondok pesantren. Pendidikan Seminari adalah pendidikan bagi para calon imam yang dikelola oleh institusi gereja katolik dalam hal ini para pastor katolik dan biarawati/biarawan katolik. Sedangkan pendidikan pesantren dikelola oleh para ulama yang mendidik para calon pemimpin muslim. Kedua lembaga ini telah secara serius bertahun-tahun lampau hingga kini mengelola dan menyelenggarakan sistem pendidikan dengan model asrama yang ketat untuk mendidik para calon pemimpin agama dan awam yang berkualitas dan yang diharapkan oleh semua kalangan. Para pemimpin keluaran (out-put) dari lembaga pendidikan ini secara nyata telah menunjukkan kemampuan dan keprofesionalitasannya bahwa mereka telah bertumbuh menjadi pemimpin bangsa dan pemimpin agama yang memberikan pengabdian secara totalitas bagi kehidupan bangsa dan agamanya.

Para pemimpin hasil tempaan itu baik pemimpin agama maupun pemimpin politik dari kalangan awam, merupakan hasil penelitian yang dilakukan selama bertahun-tahun dalam pendidikan berasrama dengan sistem pesantren dan seminari atau pendidikan berasrama model seminari dapat disebutkan antara lain: KH. Dr. Idham Kholid, KH. Wahid Hasjim, KH. Abdurrahman Wahid, Drs. Frasiskus Seda, Mgr Soegijoyopronoto, Ignatius Joseph Kasimo, dan beberapa nama terkenal lainnya. Para pemimpin ini telah menginspirasikan banyak orang untuk menjadi yang terbaik melalui pendidikan yang dilakukan secara asrama dan terpantau secara baik, seperti yang dahulu dilalui oleh tokoh-tokoh tersebut.

Adapun yang dimaksudkan dengan kultur-kultur yang sesuai yakni kulturkultur yang memungkinkan para siswa itu nantinya akan menjadi pemimpin yang terbaik di masa depan. Pembinaan dan pendampingan terjadi dalam seluruh aspek kehidupan mulai dari bangun pagi hingga istirahat malam, mulai dari doa di kamar tidur hingga berdoa secara bersama-sama di Masjid atau kelas, pembinaan rohani

Intizar, Vol. 22, No. 2, 2016 
lewat ceramah agama (taus\}iyah), halaqah, bahlsu al-masa>il. Pembinaan intelektual lewat jalur kurikulum juga ditekankan sejalan dengan penekanan pada pembinaan jalur tradisi.

Ada beberapa nilai positif dengan adanya pendidikan dengan sistem asrama ini, yakni: Pertama, pendidikan ini menekankan pentingnya kebersamaan dalam kehidupan berkomunitas (asrama). Kehidupan berkomunitas menandakan persekutuan hidup bersama. Di dalamnya terjadi saling koreksi, saling memahami, saling belajar, saling bertegur sapa, saling melayani dan saling memberi dalam kebersamaan dan solidaritas persaudaraan. Kehidupan komunitas memberi warna tertentu dalam kebersamaan. Bakat dan kemampuan individu merupakan warna tersendiri bagi kegembiraan dan harapan bersama dalam komunitas itu. Bakat dan kemampuan dalam komunitas itu ibarat bebungaan yang menambah sedap dan keindahan dalam kehidupan komunitas itu sendiri.

Kedua, pendidikan dengan model asrama memungkinkan orang mampu menyusun jadual dan mampu melaksanakan jadual itu dengan penuh disiplin. Pendidikan asrama sering dibuat berdekatan dengan pendidikan kurikulum agar para siswa dengan bantuan bimbingan dari salah seorang guru pembimbing yang telah ditentukan dapat mendiskusikan sendiri jadualnya dan mampu melaksanakan jadual-jadual yang telah disusunya secara bagus dan dengan tertib. melalui sistem asrama orang dapat dengan baik melakukan semua kegiatan dengan penuh disiplin dan tanggung jawab. Kedisiplinan menjadi kata kunci dalam pendidikan berasrama. Pengelola pendidikan berasrama harus memperhitungkan saat-saat istirahat, saat-saat makan-minum, olahraga, berbicara/ diam, mencuci, mandi, bekerja, belajar, berdoa dan bersekolah. Setiap pergantian jam kegiatan itu memerlukan ketepatan waktu yang tinggi. Kedisiplinan merupakan hal yang harus dilakukan oleh semua penghuni asrama tanpa kecuali, bila siswa itu tidak mampu hidup dalam asrama sesuai tuntutan kedisiplinan maka dia akan mendapatkan hukuman atau dia akan dikeluarkan secara tegas dari kehidupan di dalam asrama itu sendiri.

Ketiga, pendidikan asrama memungkinkan benih-benih intelektual, pembinaan emosi, benih-benih afeksi dan pembinaan spiritual-religius dapat disemaikan dengan baik. Benih-benih intelektual seperti kesempatan lebih banyak untuk berdiskusi dan mendalami bahan-bahan ajar, kesempatan lebih banyak untuk mengunjungi perpustakaan, membaca buku-buku yang bermutu dan menulis menjadi lebih banyak tersedia. Di dalam sistem asrama juga disampaikan pembinaan emosi manusia. kesabaran, ketabahan dan keuletan merupakan hal-hal

Intizar, Vol. 22, No. 2, 2016 
yang bisa diperoleh melalui latihan-latihan di dalam sistem pendidikan berasrama di sekolah dengan model pendidikan berasrama. Demikian pun kesempatan lebih banyak untuk beribadah, berdoa, pembinaan spiritual-religius dapat meningkatkan derajat keimanan para siswa. Maka melalui pembinaan rohani, latihan-latihan spiritual dan ekaristi yang intes para siswa dapat memiliki kemampuan spiritual yang tinggi dalam hidupnya.

Keempat, pembinaan sikap dan kemandirian. Melalui sistem asrama sikapsikap manusia bisa diarahkan dan dibimbing ke arah yang lebih baik. Peraturan dalam asrama menjadi faktor yang menentukan sikap-sikap tersebut. Taat kepada peraturan dengan semua tuntutan kehidupan asrama menjadi tuntutan yang mutlak perlu bila para siswa ingin bertumbuh menjadi manusia yang baik dan berkualitas di masa depan. Pendidikan berasrama menandakan kultur yang sesuai, dimana melalui penciptaan kondisi-kondisi tersebut para siswa dapat bertumbuh dan memiliki kemampuan untuk membedakan mana yang baik dan mana yang jelek, serta memilih yang baik dan menolak yang jahat/jelek dalam hidupnya.

Kelima, pendidikan kepemimpinan dan karakter para siswa. Melalui pendidikan berasrama pendidikan karakter para siswa semakin dipertinggi. Pendidikan karakter para siswa seperti pembinaan dan pembentukan kebudayaan para siswa lewat latihan muh $\} a>d\} a r a h$, khit $\} a>b a h$, marawis, had $\}$ rah, pentas seni, dan lain-lain yang memungkinkan pengembangan kebudayaan para siswa menjadi meningkat. Peningkatan karakter manusia juga dicapai melalui disiplin, latihan bela diri, tenaga dalam, olag raga. Semua ini dapat mempertinggi karakter dan kemampuan kepemimpinan para siswa. Untuk itu para pembimbing harus mampu menyusun program kegiatannya secara tertulis dan rapi.

Sehubungan dengan beberapa hal di atas, maka penting kiranya diungkapkan urgensi asrama siswa bagi SMPIT Al-Furqan Palembang yakni, sebagai pusat pewarisan budaya. Pewarisan Budaya Bangsa yang dimaksud dalam konteks ini adalah Pewarisan budaya yang muncul dari sebuah proses pemahaman tentang ajaran hidup yang mendasar. Ajaran hidup yang mendasarnya itu biasanya muncul dari pemahman ajaran agama dan filosofi kehidupan. Oleh karena itu, secara sederhana pewarisan budaya bangsa yang dianut oleh suatu komunitas tidak terlepas dari dua unsur dasar filosofi kehidupan umat manusia; yaitu agama (wahyu) dan ajaran filsafat (paradigma ilmu pengetahuan).

SMPIT Al-Furqon menganut sistem kebenaran paradigma ilmu pengetahuan dan pada sisi lain ia juga mengakui kebenaran ajaran agama yang bersumber dari wahyu. Pengakuan terhadap nilai kebenaran ilmu pengetahuan dibuktikan dengan 
diajarkannya ilmu-ilmu sekuler di dalam sekolah; yaitu dengan dibukanya ekskul seni. Sedangkan pengakuan atas nilai kebenaran wahyu atau ajaran agama dibuktikan dengan dimasukkannya materi-materi keagamaan yaitu pelajaran bahasa Arab/Imla', Hadits, Mahfudzat, Tahfidz, dan Tahsin serta Setoran Pendadaran di dalam kurikulum Asrama Sekolah Menegah Pertama Islam Terpadu (SMPIT) Al-furqon.

Memperhatikan pewarisan Sekolah Menegah Pertama Islam Terpadu (SMPIT) Al-furqon tersebut di atas dapat disimpulkan bahwa pewarisan Sekolah Menegah Pertama Islam Terpadu (SMPIT) Al-furqon merupakan pewarisan yang dibangun dari kultur pendidikan sistem pesantren/asrma sebagaimana yang terjadi di Sumatera pada umumnya. Kultur pendidikan yang berbasis dari pendidikan sistem Pesantren/asrma ini tampaknya lebih menekankan pada aspek proses pembelajaran di ruang belajar, sebagai sarana transformasi pengetahuan. Hal ini disebabkan karena memang sejak awal lembaga pendidikan Islam yang berkembang di Sumatera Selatan adalah model pendidikan sistem madrasah bukan sistem asrama sebagaimana yang berkembang di Jawa pada umumnya.

\section{Kesimpulan}

Karakter yang ingin ditanamkan kepada setiap siswa/ peserta didik di SMPIT Al-Furqan Palembang, yakni: religious, jujur, toleransi, disiplin, kerja keras, kreatif, mandiri, demokratis, peduli lingkungan, peduli sosial, dll. Karakter ini akan dicapai dengan membuat tata tertib, peraturan, panduan dan sangsi atas setiap pelanggaran. 


\section{Endnote}

${ }^{1}$ Misalnya, Abd A'la, dalam buku Pembauran Pesantren, Yogyakarta: LkiS, 2006, Martin Van Bruinessen, dalam buku, Kitab Kuning, Pesantren dan Tarekat, Bandung: Mizan, 1995, Muhammad Habib Hirzin, dalam buku Keilmuan Pesantren, Jakarta: LP3ES, 1987, Zamachsyarie Dhofier, dalam buku, Tradisi Pesantren:, Studi Tentang Pandangan Hidup Kiyai, Jakarta: LP3ES, 1985.

${ }^{2}$ William Haviland, Antropologi Jillid 2, (Jakarta : Erlangga.1985), hal. 355.

${ }^{3}$ Francis J. Brown, Educational Sosiology, (Tokyo: Charles E. Tuttle Company, 1961, Modern Asia Edition, hal. 158.

4 Nurchalis Madjid, Bilik-bilik Pesantren, Sebuah Potret Perjalanan, (Jakarta: Paramadina, 1997), hal. 99.

${ }^{5}$ Berger, Peter, L. dan Luckmann, Thomas, Tafsir Sosial atas Kenyataan, Terj. Hasan Basari, (Jakarta: LP3ES, 1990), hal. 145.

6 David Kaplan \& Albert A.Manners, Teori Budaya. (Jogyakarta : Pustaka Pelajar1999), hal.176

${ }^{7}$ Hiroko Horikoshi, Kyai dan Perubahan Sosial, (Jakarta: P3M, 1987), hal. 97.

${ }^{8}$ Zamachsyarie, Tradisi....hal. 54

${ }^{9}$ Mastuhu, Dinamika Sistem Pendidikan Pesantren, (Jakarta: INIS, 1994), hal. 154

${ }^{10}$ Choirunniswah, Sejarah Pendidikan Islam, (Palembang: IAIN Raden Fatah Press, 2006), hal. 207

${ }^{11}$ Adam Kuper, Pokok dan Tokoh Antropologi, (Jakarta : Bhratara1996), hal. 214

${ }^{12}$ PiÖrt Sztompka, The Sociology of Social Change, (Malden: Blackwell, 1998), hal. 215

\section{Daftar Pustaka}

A'la, Abd. (2006). Pembauran Pesantren. Yogyakarta: LkiS.

Berger, Peter, L. dan Luckmann, Thomas. (1990). Tafsir Sosial atas Kenyataan, Bruinessen, Martin Van. (1995). Kitab Kuning, Pesantren dan Tarekat. Bandung: Mizan.

Brown, Francis J. (1961). Educational Sosiology. Tokyo: Charles E. Tuttle Company Modern Asia Edition.

Choirunniswah. (2006). Sejarah Pendidikan Islam. Palembang: IAIN Raden Fatah Press.

Dhofier, Zamachsyarie. (1985). Tradisi Pesantren: Studi Tentang Pandangan Hidup Kiyai. Jakarta: LP3ES.

Haviland, William. (1985). Antropologi Jillid 2. Jakarta: Erlangga.

Hirzin, Muhammad Habib. (1987). Keilmuan Pesantren. Jakarta: LP3ES.

Horikoshi, Hiroko. (1987). Kyai dan Perubahan Sosial. Jakarta: P3M.

Kaplan, David \& Albert A. Manners. 1999. Teori Budaya. Yogyakarta: Pustaka Pelajar.

Intizar, Vol. 22, No. 2, 2016 
Kuper, Adam. (1996). Pokok dan Tokoh Antropologi. Jakarta: Bhratara.

Madjid, Nurchalis. (1997). Bilik-bilik Pesantren, Sebuah Potret Perjalanan. Jakarta: Paramadina.

Mastuhu. (1994). Dinamika Sistem Pendidikan Pesantren. Jakarta: INIS.

Sztompka, PiÖrt. (1998). The Sociology of Social Change. Malden: Blackwell.

Terj. Hasan Basari, Jakarta: LP3ES. 